\title{
Upper Cretaceous radiolarians reworked in the Eocene London Clay Formation, SE England
}

\author{
Tom Fer' ${ }^{1}$, Taniel Danelian ${ }^{*}$ \& Haydon W. Bailey ${ }^{2}$ \\ ${ }^{1}$ Université de Lille - Sciences et Technologies, CNRS, UMR 8198 Evo-Eco-Paleo, F 59655 Villeneuve d'Ascq, France \\ ${ }^{2}$ Network Stratigraphic Consulting Ltd, Harvest House, Cranborne Road, Potters Bar, Hertfordshire EN63JF, UK \\ *Correspondence: taniel.danelian@univ-lille1.fr
}

\begin{abstract}
Radiolarians were recently discovered in the lower Eocene London Clay Formation of the London Basin from samples in a drainage borehole in the River Thames. They come from a $c .10 \mathrm{~m}$ thick sequence of silty shales in the lower part of the formation. The radiolarians are, in general, rather poorly preserved, with the exception of six samples that yielded moderately preserved radiolarians that allowed the identification of eighteen taxa. All radiolarians observed are of Late Cretaceous age and they are therefore reworked into the lower part of the Eocene London Clay Formation. The best preserved sample yielded an assemblage of twelve morphospecies, including Diacanthocapsa ovoidea, Theocapsomma amphora and Theocapsomma sp. aff. T. amphora sensu Popova-Goll et al. 2005, suggesting an original Santonian-Campanian age, and more likely only the Campanian. However, the stratigraphic origin of these radiolarians from the Upper Cretaceous sequence of the London Basin is uncertain.
\end{abstract}

Keywords: London Clay Formation; Eocene; Upper Cretaceous; radiolarians; London Basin

Received 23 December 2014; accepted 25 November 2015

Over the last 20 years a large number of taxonomic and biostratigraphic studies have been devoted to Cretaceous radiolarians from Europe, but the majority of them concern Tethyan basins in Spain and Italy (Jud 1994; O'Dogherty 1994), Montenegro (Gorican 1994), Greece (Danelian et al. 2002; Danelian 2008), Poland (Bak 1995, 1996; Bak \& Sawlowicz 2000) and the Czech Carpathians (Smreckova 2011). Cretaceous radiolaria from the NW European and Boreal realm are much less well known; the few data available come from the Danish Trough, where radiolarians have been described from Coniacian to Santonian sequences (Packer \& Hart 2005). In the UK, rare radiolarians were reported at the end of the nineteenth century (Rüst 1888; Hill \& Jukes-Browne 1895; Holmes 1900) from the Upper Cretaceous, mainly Turonian, chalk (Melbourn Rock) of the London Basin (Fig. 1), but there is no modern taxonomic study.

Recently, we discovered moderately well-preserved radiolarians in London Basin sediments from a borehole drilled by Thames Water Utilities Ltd in the River Thames in London. They come from the London Clay Formation (Fig. 2), which is Ypresian (early Eocene) in age and rather rich in microfossils where they are preserved. In terms of siliceous microfossils, only diatoms have been identified before from this formation in an unpublished report by C. King. This is, therefore, the first report of radiolarians from the London Clay. They appear to be Late Cretaceous in age and, thus, reworked in the lower Eocene London Clay Formation. Following a taxonomic account of the radiolaria identified, the material is compared with coeval assemblages known worldwide (i.e. Denmark and the Russian platform: Vishnevskaya \& De Wever 1998; Popova-Goll et al. 2005).

\section{Geological and stratigraphic settings}

The London Basin of SE England is a $250 \mathrm{~km}$ long sedimentary basin, the sequences of which also crop out in the northern Dieppe and Hampshire Basin (Fig. 1). It is a large synclinal fold, formed during the Alpine orogeny (Oligocene to mid Miocene). The major part of the basin is filled with Upper Cretaceous chalk sequences (Mortimore 2011). Only the uppermost part of the Upper Cretaceous is relevant to this study, but the full Upper Cretaceous and Palaeogene sequence is shown in Figure 2.

The Upper Cretaceous Chalk Group is 150-250 m thick; it is less expanded than the chalk of the Dieppe and Hampshire Basin, where its thickness exceeds $400 \mathrm{~m}$ (Royse 2010). Figure 2 displays all the nine mapping formations recognized for the onshore Chalk of England (Hopson 2005). The two lowermost Chalk formations, of Cenomanian age, contain numerous marly intervals. More particularly, the West Melbury Marly Chalk is characterized by couplets of soft, marly levels and limestone beds. The overlying Zig Zag Chalk, although it contains rhythmic alternations of marls, marly chalk and chalk, is mostly characterized by firm beds of chalk. The wellknown Plenus Marls, which accumulated during the late Cenomanian critical interval of the Oceanic Anoxic Event 2, are situated at the base of the Holywell Chalk Formation, the general lithology of which is characterized by hard nodular chalk with abundant shell debris. The Melbourn Rock Member, in which Hill \& Jukes-Browne (1895) observed radiolarians in thin sections of nodules, overlies conformably the Plenus Marls and is characterized by the absence of bioclasts. The New Pit Chalk Formation is made essentially of firm chalk beds that include numerous marly intercalations and sporadic flint in the deeper sequences. The Lewes Chalk Formation is characterized by massive beds of hard nodular chalk and hardgrounds and includes some regular seams of nodular flint (chert). The overlying Seaford Chalk Formation is made of "white chalk with conspicuous semi-continuous nodular and tabular flint seams' (Hopson 2005, p. 25). The Newhaven Chalk Formation is characterized by rather soft and white chalk beds intercalated by frequent marl seams and flint bands. The Culver Chalk Formation is of rather similar lithology with the underlying Newhaven Chalk but there is relatively little marl. Finally, the Portsdown Chalk Formation displays marl seams intercalated in the white chalk, which is at some levels rich in inoceramid debris, but its flint bands are much less developed than in the Culver Chalk. 


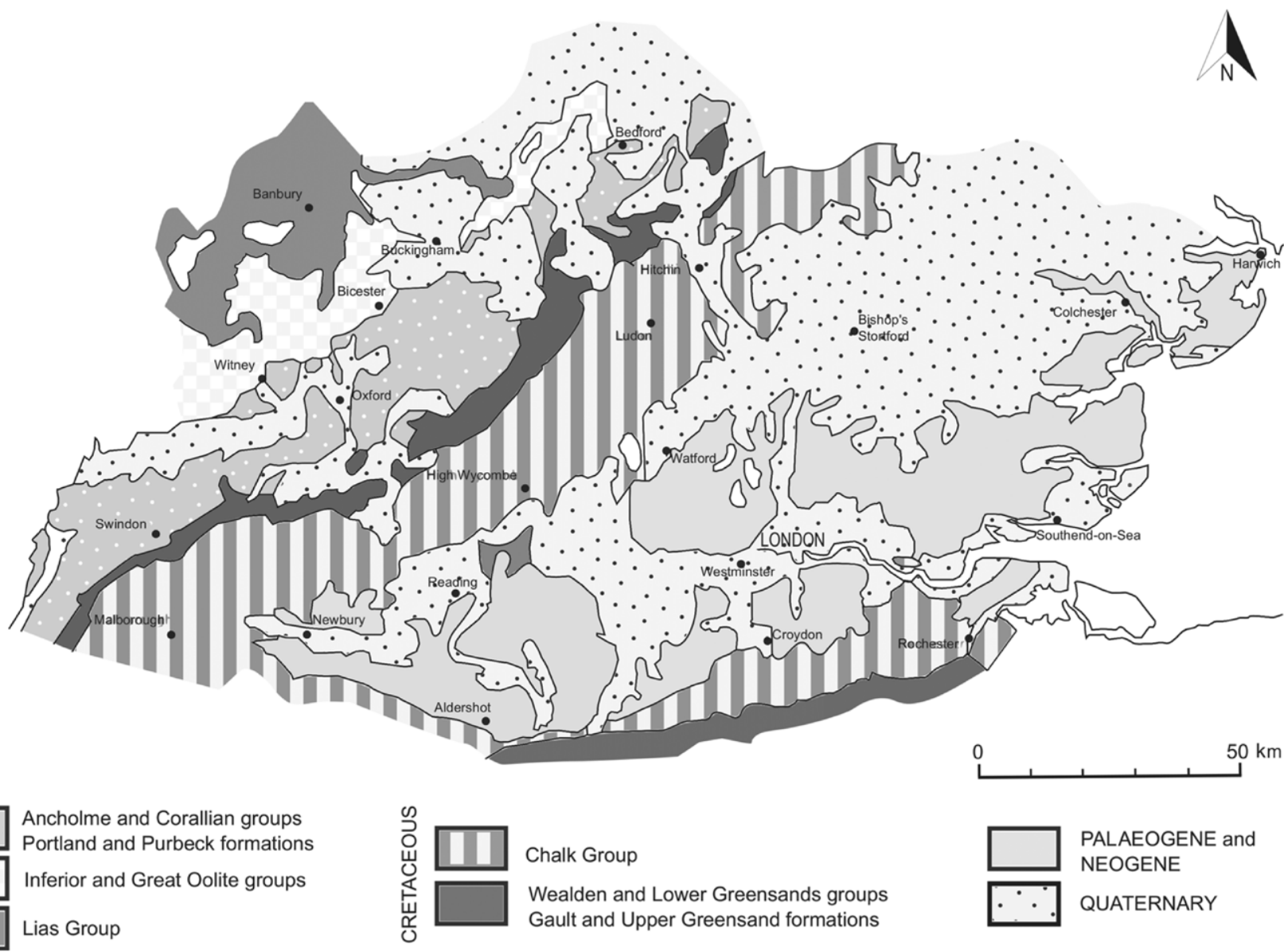

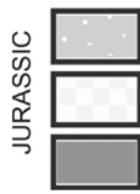

Ancholme and Corallian groups Portland and Purbeck formation Lias Group

Fig. 1. Geological map of the London Basin (after Royse 2010).

The Thanet Sand Formation is the oldest deposit of the Paleocene sequence in the basin. This unit is followed by a succession of three formations: Woolwich, Reading and Upnor formations, which are part of the Lambeth Group (Ellison et al. 2004). The Eocene Harwich Formation overlies the Lambeth Group; it is mainly composed of sand, clayey sand and pebbles. This thin formation is overlain by the Ypresian London Clay Formation which is composed of brownish clay and silty clay $90-130 \mathrm{~m}$ thick (Ellison et al. 2004). This formation is the thickest part of the Palaeogene; together with the Harwich Formation, it comprises the Thames Group. It is in the London Clay Formation that radiolarians were found during this study.

\section{Stratigraphy of the studied well}

The borehole SR 5019 (90 m deep) was drilled by Thames Water Utilities Ltd as a test borehole for the Thames Tideway project, in the Barnes neighbourhood of Richmond, west London. This well penetrates the London Clay Formation, the Harwich Formation, the Lambeth Group and the Thanet Sand Formation (Fig. 3). The London Clay Formation extends from 6 to $48.42 \mathrm{~m}$ below the surface and may be divided from the top down as follows:

(1) Unit B (18.5 m thick) - homogeneous grey-brown to brown clay, rich in glauconite, grey claystones, rare nodules of pyrite and rare layers of fine sand, with a $1 \mathrm{~m}$ thick bed of grey silty clay at the base. Foraminifera and some sponge spicules were found in the lower part of the unit.

(2) Unit A3ii (9.45 m thick) - grey-brown clay with glauconite and silt and very fine sand partings. This unit is rich in foraminifera and calcareous nannofossils.
(3) Unit A3i (2 $\mathrm{m}$ thick) - similar lithology to unit B. Homogeneous brownish clay with thin beds of grey claystones associated with calcite veins. Few microfossils occur in this unit. The boundary between units A3ii and A3i is not well defined.

(4) Unit A2 (12.42 m thick) - silty clay beds with small pockets of silt interbedded with greyish-brown sandy silty clay with greenish silt and burrows filled with white silt. A2 is rich in foraminifera and it is in this unit that radiolarians were found. The base of this unit is marked by a very high concentration of bivalve debris.

Below A2 is a $0.5 \mathrm{~m}$ thick interval of sands and clays, rich in glauconite, with shell debris and pockets of brown sand; this unit is the Harwich Formation.

\section{Material and methods}

Six sediment samples were washed with a $63 \mu \mathrm{m}$ mesh sieve. Microfossils were picked with a thin brush, under a stereo-binocular microscope, and then placed on slides. Several groups of microfossils were found, including foraminifera, molluscs and radiolarians. The specimens were photographed with a scanning electron microscope.

\section{Taxonomy}

For the taxonomic concepts used at family level we have followed De Wever et al. (2001) and at genus level O'Dogherty et al. (2009). A small selection of references is given under each synonymy to clarify the accepted morphological variability at species level. 


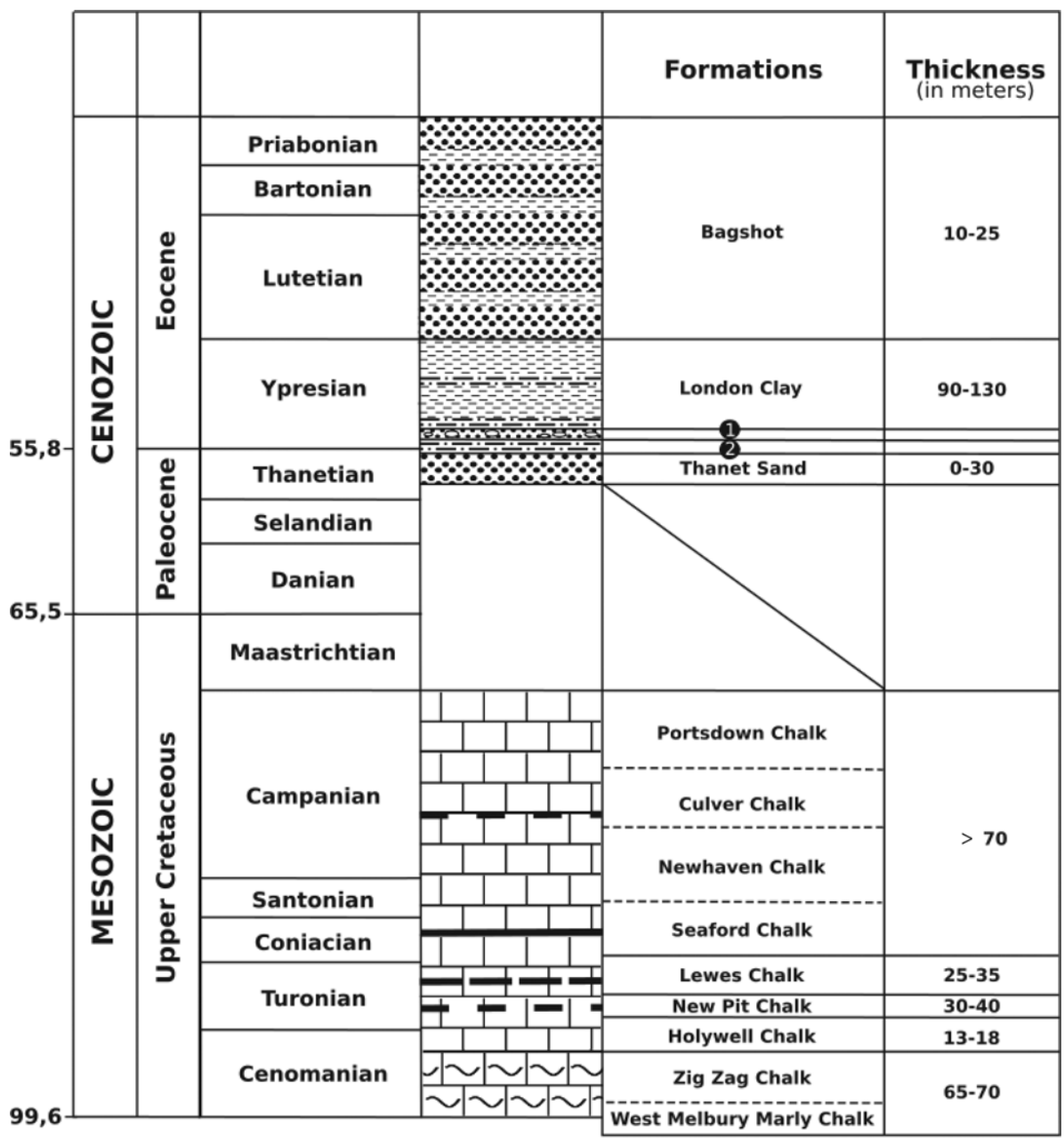

\section{Legend}

\begin{tabular}{|c|c|c|c|}
\hline 告 & Marly Limestone & 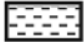 & Clay \\
\hline 巴 & Limestone & E्व & Level of chert \\
\hline 匡코 & Silt & \%0: & Pebbles \\
\hline$\%$ & Sand & & \\
\hline
\end{tabular}

Order Nassellaria Ehrenberg, 1875

Family Amphipyndacidae Riedel, 1967

Genus Amphipyndax Foreman, 1966, emend. Empson-Morin, 1981

Amphipyndax stocki (Campbell \& Clark, 1944)

(Fig. 4: 6, 21)

1944 Stichocapsa (?) stocki Campbell \& Clark: 44; 1. 18, figs 31-33.

1982 Amphipyndax stocki (Campbell \& Clark); Taketani: 52; pl. 10, figs 13,14

2005 Amphipyndax stocki (Campbell \& Clark); Popova-Goll et al.: 10 ; pl. 5 , fig. 6 .

2007 Stichomitra stocki (Campbell \& Clark); Musavu-Moussavou et al.: 273; pl. 4 figs 9-10 (only).

Material. 2 specimens.

Family Archaeodictyomitridae Pessagno, 1976
Genus Archaeodictyomitra Pessagno, 1976

Archaeodictyomitra sp. cf. A. simplex Pessagno, 1977

(Fig. 4: 20, 22)

cf. 1977 Archaeodictyomitra simplex Pessagno: 43, pl. 6, figs. 1, 24; pl. 12, fig. 12.

Remarks. Two incomplete or poorly preserved specimens that display $11-13$ continuous costae visible in a lateral view, running throughout an elongate, conical test, which is only gently affected by slight constrictions.

Archaeodictyomitra sp. cf. A. squinaboli Pessagno, 1976

(Fig. 4: 23, 26)

cf. 1976 Archaeodictyomitra squinaboli Pessagno: 50; pl. 5, figs $2-8$.

Material. 2 specimens.

Remarks. From their general test outline which is affected by gentle segmental constrictions, the number of their postabdominal 


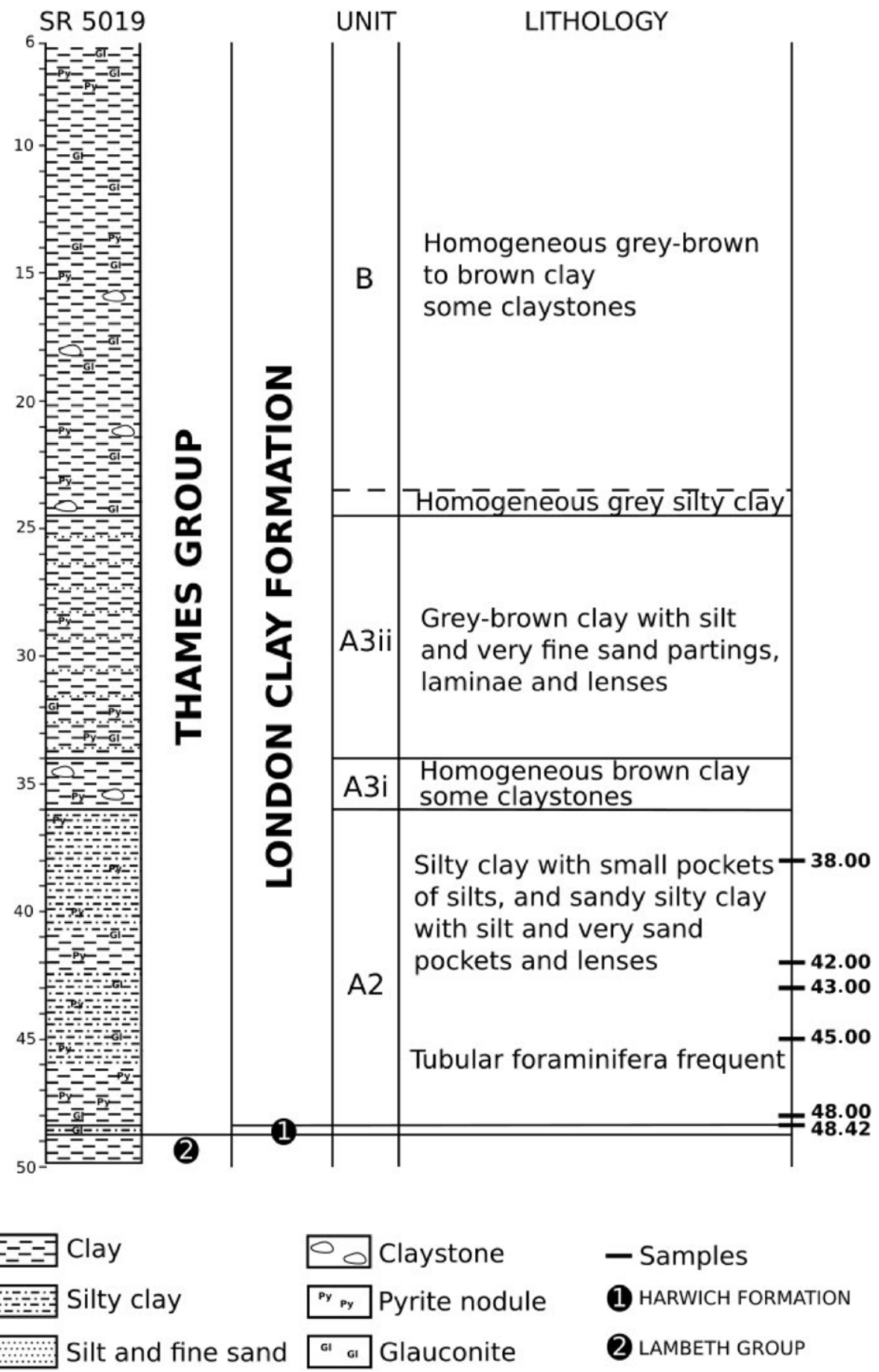

Fig. 3. Lithostratigraphic column of borehole SR 5019, with positions of radiolarian-bearing samples. segments and number of costae, the illustrated specimens resemble A. squinaboli.

Genus Dictyomitra Zittel, 1876, emend. Pessagno, 1976

?Dictyomitra napaensis Pessagno, 1976

(Fig. 4: 18-19)

?1976 Dictyomitra napaensis Pessagno: 53; pl. 4, fig. 16; pl. 5, figs $1,9$.

Material. 2 specimens.

Remarks. In spite of their poor preservation, the specimens resemble $D$. napaensis by the lobate subcylindrical outline of their test, displaying 12 to fifteen costae visible in lateral view.
Family Cannobotryidae Haeckel, 1881

Genus Rhopalosyringium Campbell \& Clark, 1944

Rhopalosyringium (?) sp.

(Fig. 4: 7, 15)

Material. 10 specimens.

Remarks. Although all observed specimens display a small hemispherical cephalis, no horn was observed, probably because the proximal part is always rather poorly preserved. The large subspherical thorax is perforated by circular pores surrounded by polygonal (mostly hexagonal) pore frames.

Family Carpocaniidae Haeckel, 1881 


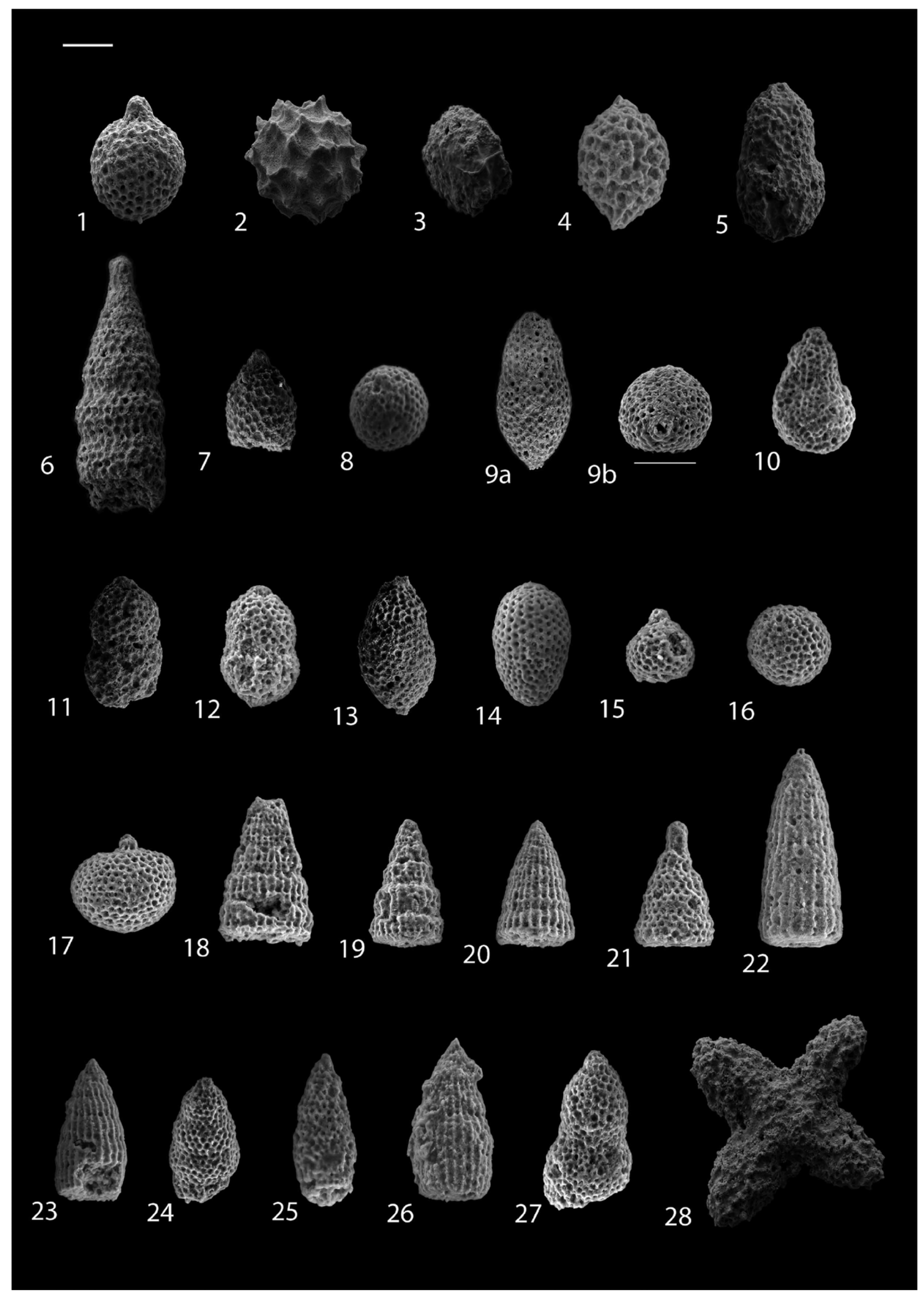

The caption to Figure 4 can be found on p.138. 
Genus Diacanthocapsa Squinabol, 1903, emend. Dumitrica, 1970

Diacanthocapsa ovoidea Dumitrica, 1970

(Fig. 4: 9a-b, 13)

1970 Diacanthocapsa ovoidea Dumitrica: 63; pl. V, figs 25a-b; pl. VI, figs 26-29a, b.

1997 Diacanthocapsa ovoidea Dumitrica; Hashimoto \& Ishida: pl. 3, fig. 1 .

2001 Diacanthocapsa ovoidea Dumitrica; Hollis \& Kimura: 248.

Material. 2 specimens.

Occurrence and age. Lower Campanian of Valea Mare, Romania (Dumitrica 1970), upper Campanian of Shikoku island, Japan (Hashimoto \& Ishida 1997).

Remarks. The laterally open aperture situated at the end of the oval abdomen appears to be slightly broken in our material. Our specimens are smaller (total height 117 and $138 \mu \mathrm{m}$ ) than those described by Dumitrica (1970; total height 170-200 $\mu \mathrm{m})$.

\section{Diacanthocapsa sp. A}

(Fig. 4: 14)

Material. 1 specimen.

Remarks. Egg-shaped general outline, with a clear constricture delimiting the thorax from the abdomen. Continuous rows of pores are equally widespread.

Genus Theocapsomma Haeckel, 1887 emend. Foreman, 1968

Theocapsomma amphora Campbell \& Clark, 1944

(Fig. 4: 5, 10, 27)

1944 Theocapsa (Theocapsomma) amphora Campbell \& Clark: 35; pl. 7, figs 30-31.

1997 Theocapsomma amphora Campbell \& Clark; Hollis: pl. 15, figs $1-2$.

2005 Theocapsomma amphora Campbell \& Clark; Popova-Goll et al.: 26; pl. 1, fig. 3; pl. 7, fig. 11.

Material. 3 specimens.

Occurrence and age. Campanian-Paleocene, California, Atlantic and SW Pacific (Hollis 1997; Popova-Goll et al. 2005), SantonianUpper Campanian, Russia (Popova-Gall et al. 2005).

Theocapsomma sp. aff. T. amphora Campbell \& Clark, 1944 sensu Popova-Goll et al., 2005

(Fig. 4: 11-12)

2005 Theocapsomma sp. aff. T. amphora Campbell \& Clark; Popova-Goll et al.: 26; pl. 1, fig. 2; pl. 3, fig. 17.
Material. 2 specimens.

Occurrence and age. Santonian-Lower Campanian of Russian platform (Popova-Goll et al. 2005).

Remarks. As mentioned by Popova-Goll et al. (2005), this species is distinguished from T. amphora by its third segment being smaller and less swollen, which results in a rather cylindrical outline.

Family Eucyrtidiidae Ehrenberg, 1847

Genus Stichomitra Cayeux, 1897

Stichomitra sp. cf. S. manifesta Foreman, 1978

(Fig. 4: 24)

cf. 1903 Stichomitra communis Squinabol: 141; pl. 8, fig. 40.

cf. 1978 Stichomitra manifesta Foreman: 748; pl. 5, fig. 4.

cf. 1981 Novodiacanthocapsa manifesta (Foreman); EmpsonMorin: 270; pl. 9, figs 2A-4D.

cf. 1982 Stichomitra manifesta Foreman; Taketani: 55; pl. 3, fig. 8a-b; pl. 11, figs 7-8.

cf. 2001 Stichomitra ex. gr. manifesta Foreman; Vishnevskaya: pl. 7 , fig. 9 .

Material. 2 specimens.

Remarks. Doubts about identification are due to poor/incomplete preservation.

\section{Stichomitra sp. A}

(Fig. 4: 25)

Remarks. One single specimen perforated with small pores throughout the test. Proximal part incomplete. Segmental constrictions very subtle.

Family Sethocapsidae Haeckel, 1881

Genus Sethocapsa Haeckel, 1881

?Sethocapsa orca Foreman, 1975

(Fig. 4: 17)

?1975 Sethocapsa (?) orca Foreman: 617; pl. 2J, figs 1-2, pl. 6, fig. 12.

?2011 Sethocapsa orca Foreman; Kurilov \& Vishnevskaya: pl. 3, fig. 2 .

Material. 1 specimen.

Remarks. Proximal part poorly preserved. Abdomen subspherical, perforated all over with circular pores.

Family Williriedellidae Dumitrica, 1970

Fig. 4. Scanning electron micrographs of radiolaria from samples $42.0 \mathrm{~m}$ (figs 1-2), $43.0 \mathrm{~m}$ (figs 3-6), $45.0 \mathrm{~m}$ (figs 7-9b), $48.0 \mathrm{~m}$ (figs 10-24) and $48.42 \mathrm{~m}$ (figs 25-28). Scale bars $50 \mu \mathrm{m}$ for all specimens. 1, Cryptamphorella sp. cf. C. sphaerica (White); 2, Praeconocaryomma (?) sp. cf. P. californiaensis Pessagno; 3, ?Orbiculiforma multa Kozlova; 4, Praestylosphaera (?) sp.; 5, Theocapsomma amphora Campbell \& Clark; 6, Amphipyndax stocki (Campbell \& Clark); 7, Rhopalosyringium (?) sp.; 8, Cryptamphorella (?) sp. cf. C. sphaerica (White); 9a, b, Diacanthocapsa ovoidea Dumitrica, profile and apertural view (respectively) of the same specimen; 10, Theocapsomma amphora Campbell \& Clark; 11-12, Theocapsomma sp. aff. T. amphora Campbell \& Clark sensu Popova-Goll et al.; 13, Diacanthocapsa ovoidea Dumitrica; 14, Diacanthocapsa sp. A; 15, Rhopalosyringium (?) sp.; 16, Cryptamphorella (?) sp. cf. C. sphaerica (White); 17, ?Sethocapsa orca Foreman; 18-19, ?Dictyomitra napaensis Pessagno; 20, Archaeodictyomitra sp. cf. A. simplex Pessagno; 21, Amphipyndax stocki (Campbell \& Clark); 22, Archaeodictyomitra sp. cf. A. simplex Pessagno; 23, Archaeodictyomitra sp. cf. A. squinaboli Pessagno; 24, Stichomitra sp. cf. S. manifesta Foreman; 25, Stichomitra sp. A; 26, Archaeodictyomitra sp. cf. A. squinaboli Pessagno; 27, Theocapsomma amphora Campbell \& Clark; 28, ?Crucella crux (Lipman). 
Table 1. Radiolarian occurrence in the studied samples from borehole SR 5019

\begin{tabular}{|c|c|c|c|c|c|c|}
\hline \multirow[b]{2}{*}{ Species } & \multicolumn{6}{|c|}{ Samples ( $\mathrm{m}$ below surface) } \\
\hline & 38.00 & 42.00 & 43.00 & 45.00 & 48.00 & 48.42 \\
\hline Amphipyndax stocki & & & $\mathrm{x}$ & & $\mathrm{x}$ & \\
\hline Archaeodictyomitra sp. cf. A. simplex & & & & & $\mathrm{x}$ & \\
\hline Archaeodictyomitra sp. cf. A. squinaboli & & & & & $\mathrm{x}$ & $\mathrm{x}$ \\
\hline ?Crucella crux & & & & & & $\mathrm{x}$ \\
\hline Cryptamphorella sp. cf. C. sphaerica & $?$ & $\mathrm{x}$ & $?$ & $?$ & $?$ & $?$ \\
\hline Diacanthocapsa ovoidea & & & & $\mathrm{x}$ & $\mathrm{x}$ & \\
\hline Diacanthocapsa sp. A & & & & & $\mathrm{x}$ & \\
\hline ?Dictyomitra napaensis & & & & & $\mathrm{x}$ & \\
\hline ?Orbiculiforma multa & $\mathrm{x}$ & & $\mathrm{x}$ & & & \\
\hline Praeconocaryomma (?) sp. cf. $P$. californiaensis & & $\mathrm{x}$ & & & & \\
\hline Praestylosphaera (?) sp. & & & $\mathrm{x}$ & & & $\mathrm{x}$ \\
\hline Rhopalosyringium (?) sp. & $\mathrm{x}$ & & $\mathrm{x}$ & & $\mathrm{x}$ & $\mathrm{x}$ \\
\hline ?Sethocpasa orca & & & & & $\mathrm{x}$ & \\
\hline Stichomitra sp. cf. S. manifesta & & & $\mathrm{x}$ & & $\mathrm{x}$ & \\
\hline Stichomitra sp. A & & & & & & $\mathrm{x}$ \\
\hline Theocapsomma amphora & & & $\mathrm{x}$ & & $\mathrm{x}$ & $\mathrm{x}$ \\
\hline Theocapsomma sp. aff. T. amphora & & & $\mathrm{x}$ & & $\mathrm{x}$ & \\
\hline Total number of specimens & 22 & 18 & 49 & 26 & 202 & 48 \\
\hline
\end{tabular}

Genus Cryptamphorella Dumitrica, 1970

Cryptamphorella sp. cf. C. sphaerica (White, 1928)

(Fig. 4: 1, ?8, ?16)

cf. 1928 Baculogypsina (?) sphaerica; White: 306; pl. 41, figs 12-13.

cf. 1970 Cryptamphorella sphaerica (White); Dumitrica: 82; pl. XII, figs 73a-b, 74a-c, 75a-b, 76, 77; pl. XX, figs 133a-b, c-f.

cf. 2004 Cryptamphorella sphaerica (White); Bragina: S383; pl. 12 , fig. 7 ; pl. 31, fig. 3; pl. 32, fig. 4.

cf. 2005 Cryptamphorella sphaerica (White) Dumitrica; PopovaGoll et al.: 11-12; pl. 1, fig. 6; pl. 6, fig. 1.

Material. 1 specimen.

Remarks. The illustrated specimen closely resembles $C$. sphaerica and its dimensions are similar to those given by Dumitrica (1970). Doubts regarding its identification lie with the preservation of its proximal part that does not allow observation of longitudinal ridges developed on its cephalis, and because we did not observe a sutural pore. All the studied samples contain spherical forms at different stages of preservation (e.g. Fig. 4: 8, 16) which may also belong to this species.

Order Spumellaria Ehrenberg, 1875 emend.

De Wever et al., 2001

Family Hagiastridae Riedel, 1971

Genus Crucella Pessagno, 1971

?Crucella crux (Lipman, 1952)

(Fig. 4: 28)

?1952 Histiastrum crux Lipman: 34; pl. 2, fig. 4.

?2005 Histiastrum crux Lipman; Popova-Goll et al.: 14; pl. 7, fig. 5.

Family Orbiculiformidae, Pessagno, 1973

Genus Orbiculiforma Pessagno, 1973
?Orbiculiforma multa Kozlova in Kozlova \& Gorbovetz 1966

(Fig. 4: 3)

?1966 Spongodisus ?multus Kozlova; Kozlova \& Gorbovetz: 87-88; pl. 4, fig. 10 .

?1998 Orbiculiforma multa Kozlova; Vishnevskaya \& De Wever: 247-248; pl. 1 figs 2, 3, 6, 9; pl. 2, fig. 13.

?2005 Orbiculiforma multa Kozlova; Packer \& Hart: 152; fig. 7A.

Material. 2 specimens.

Remarks. In spite of their poor preservation, the specimens retrieved are composed of a cylindrical test made of two disks.

Family Praeconocaryommidae Pessagno, 1976

Genus Praeconocaryomma Pessagno, 1976

Praeconocaryomma (?) sp. cf. P. californiaensis Pessagno, 1976

(Fig. 4: 2)

cf. 1976 Praeconocaryomma californiaensis; Pessagno: 41, pl. 7, figs $1-8$.

cf. 2005 Praeconocaryomma californiaensis Pessagno; PopovaGoll et al.: 20, pl. 3, figs 5-6; pl. 6, fig. 10.

Material. 1 specimen.

Remark. Internal mould, displaying mammae arranged after a hexagonal pattern.

\section{Family Stylosphaeridae Haeckel, 1881}

Genus Praestylosphaera Empson-Morin, 1981

Praestylosphaera (?) sp.

(Fig. 4: 4)

Material. 1 specimen.

Remarks. Based on the observed subspherical lattice shell, made of polygonal (mostly hexagonal) pore frames surrounding circular 
pores, this specimen is tentatively assigned to the genus Praestylosphaera. The two polar spines appear to be broken.

\section{Radiolarian distribution and preservation}

In spite of the overall poor preservation of the radiolarians, nearly half of the specimens retrieved in our material could be identified (Table 1). Spumellaria appear to be more abundant than Nassellaria in all samples.

Sample 38.00 mbs (metres below surface) yielded a very poorly preserved fauna, in which several Orbiculiforma-like specimens, two multicyrtid Nassellarians and one possible Rhopalosyringium were recognized. Although the number of radiolarians in sample $42.00 \mathrm{mbs}$ is the lowest found and their state of preservation rather poor, two were identifiable with previously described species. Some taxa identified in this study were found only in this sample, thus contributing to improving understanding of the overall diversity preserved in the studied sequence. This is especially true for Cryptamphorella sp. cf. C. sphaerica (Fig. 4: 1), but also for the internal mould tentatively assigned to Praeconocaryomma californiaensis (Fig. 4: 2).

The radiolarian preservation is much better in sample $43.00 \mathrm{mbs}$ in which Theocapsomma amphora and Amphipyndax stocki (Fig. 4: $5,6)$ were identified. The presence of specimens resembling Orbiculiforma multa and Praestylosphaera is also of significance (Fig. 4: 3, 4), as these morphotypes were found only in sample 43.00 .

Although the number of identifiable radiolaria is low in sample $45.00 \mathrm{mbs}$, a well-preserved specimen of Diacanthocapsa ovoidea was found in it (Fig. 4: 9a, b).

Sample $48.00 \mathrm{mbs}$ is the most interesting of the six samples, because of both the large number of specimens and their better preservation. Out of a total of c. 200 specimens, one-third was sufficiently well preserved to be identified. In addition to several archaeodictyomitrid morphotypes, an interesting diversity of carpocaniid morphospecies was also found in which a distinctive morphotype was identified, Theocapsomma sp. aff. T. amphora sensu Popova-Gall et al. 2005 (Fig. 4: 11-12), known previously only from the Santonian to early Campanian interval of the southern Russian platform.

Finally, radiolarians are again much less well preserved in sample $48.42 \mathrm{mbs}$; however, some morphotypes were found only in this sample (i.e. ?Crucella crux, Stichomitra sp. A).

\section{Discussion}

We discuss here the chronostratigraphic significance of the identified radiolarian taxa and their possible origin from the Cretaceous sequences of the London Basin.

Amphipyndax stocki is a world-wide species known from most of the Upper Cretaceous-Paleocene interval (Popova-Goll et al. 2005). As discussed earlier, Diacanthocapsa ovoidea is known from lower Campanian levels of Romania and upper Campanian strata of Japan. Dumitrica (1970) reports its presence in a poorly time-constrained interval covering the Turonian to Maastrichtian in Italy. Theocapsomma amphora is known from the Santonian to Paleocene (see above), while Theocapsomma sp. aff. T. amphora is known only from the Santonian to lower Campanian of the Russian Platform (Popova-Goll et al. 2005).

For some other species, although they were not identified with confidence, it is interesting to review their currently known age range as they might provide some additional evidence for the age of the original radiolarian-bearing strata. Thus, Cryptamphorella sphaerica is known mainly from the Coniacian-Santonian of Japan (Okamoto et al. 1994), the Santonian-lower Campanian of SW Russia (Popova-Goll et al. 2005) and the lower Campanian of the Caribbean region (Pessagno 1963) and of Romania (Dumitrica 1970). Orbiculiforma multa is known from the ConiacianSantonian of Denmark (Packer \& Hart 2005) and of Russia (Vishnevskaya \& De Wever 1998).

In summary, based on the presence of Diacanthocapsa ovoidea, Theocapsomma amphora and Theocapsomma sp. aff. T. amphora sensu Popova-Goll et al. (2005), the only possible common source interval of the identified radiolaria appears to be the SantonianCampanian, and more likely only the Campanian. The specimens found in the London Clay Formation are therefore definitely reworked from older formations of the London Basin.

The sedimentary sequences of the London Basin dated as Coniacian-early Campanian are the Lewes Chalk, Seaford Chalk and Newhaven Chalk formations (see Fig. 2). The Lewes Chalk Formation, of late Turonian to early Coniacian age, is composed of massive chalk with some seams of flint nodules. Based on the age of this formation, it does not seem likely to be the formation of origin for the discovered radiolaria. The Seaford Chalk Formation, of late Coniacian-early Santonian age, is composed of limestones with numerous layers of flint. One possibility is that radiolarians come from this formation. It is worth noting that the early Santonian corresponds to a transgressive interval, which would have favoured the abundance of planktonic organisms, such as radiolarians; however, none has been recorded from the extensive studies of chalks of this age in this region. The Newhaven Chalk Formation is Santonian to early Campanian in age and is characterized by white chalk that includes numerous flint layers. Therefore, such a lower Campanian level could possibly be the source of the radiolaria found reworked in the Eocene London Clay Formation. It should also be stressed that Packer \& Hart (2005) mention the presence of a silicified level at the base of the lower Campanian chalk of the Trunch borehole (north Norfolk, UK) in which they observed siliceous moulds of foraminifera. Previous reports on radiolarian occurrences from the Chalk Group in England date from the end of the nineteenth century; most were based on thin-section observations with only some radiolarian drawings amongst them. Rüst (1888) described a new radiolarian species (Dictyomitra anglica) from flints of the Upper Chalk; however, the single illustrated specimen of this multicyrtid Nassellarian is inadequately documented and should be considered as nomen dubium. Hill \& JukesBrowne (1895, p. 601) reported that they have searched for radiolarians in 'almost all the various divisions of the Chalk, from many different localities', but they have found them, calcitized, only in nodules of the Melbourn Rock. As mentioned earlier, this member is part of the Holywell Chalk Formation and spans the Cenomanian/Turonian transition. The observed calcitized radiolarians were found only in nodular beds of the Melbourn Rock, which represent, according to the authors (Hill \& Jukes-Browne 1895, p. 602), semi-consolidated chalk-ooze that 'rolled into lumps on the sea-bottom under the influence of currents'. It is worth noting that they observed radiolarians in nodules from a large area covering Cambridgeshire, Bedfordshire, Oxfordshire, Lincolnshire, Yorkshire and Dover. Some of the illustrated specimens may belong to the Late Cretaceous genus Patellula; however, their drawings (based on thin-section observations) are not sufficient for more detailed identification. Holmes (1900) published on radiolarians coming from flints of the Upper Chalk at Couldson (southern part of the Greater London area, Surrey). The radiolarians he described come from two loose flint samples found on the pile of stones left from the railway cuttings following the newly opened railway line in the area. Although 'the exact horizon from which they were derived is difficult to determine', based on the presence of echinoids and brachiopods in the same pile of rock-cuttings, the author concludes that it is very likely that the radiolarian-bearing samples come from the flint horizons present in the Sternotaxis plenus Zone (upper Turonian) of the Lewes Chalk Formation 
(Holmes 1900, p. 695). It is noteworthy that he obtained his material from the 'mealy substance, which is contained in the cavity between the central core and the outer coating', following treatment with dilute hydrochloric acid. The description of Holmes (1900) corresponds to the Lewes Tubular Flints illustrated by Mortimore (2011, fig. 11) from the Bridgewick Pit. The radiolarians he illustrated are, therefore, drawings of whole specimens and O'Dogherty (1994) was able to identify a number of species, four of which with certainty (Crucella irwini, Dictyomitra multicostata, Pseudodityomitra tiara and Stichomitra communis).

Despite numerous micropalaeontological investigations of the Coniacian-Campanian chalks of this region by, amongst others, Earland (1939), Barr (1962) and Wilkinson (2011), none of these authors has recorded any evidence of radiolaria.

One other potential resource which might include Upper Cretaceous radiolaria from southern England would be the collections made by Curry from internal flint meal residues derived from various chalk sections (Curry 1986). However, despite extensive searches at the Natural History Museum, London and University College London, these important microfossil slide collections have not been found.

\section{Conclusions}

Several hundred radiolarian specimens were recovered from the lower part of the lower Eocene London Clay Formation of the London Basin. The most diagnostic radiolarians amongst the identified specimens suggest a Late Cretaceous age (Coniacian to Campanian, possibly only Campanian) and they are therefore reworked into the early Eocene age London Clay Formation. However, the source of this radiolarian material remains uncertain and further research is necessary to identify the radiolarian-bearing levels. Radiolarians from the Chalk of the London Basin reported in the nineteenth century are either not sufficiently accurate for detailed identifications (thin-section observations) or are part of fairly different assemblages (i.e. Turonian).

\section{Acknowledgements and Funding}

P. Recourt helped with the SEM. Constructive remarks by V. Vishnevskaya and the Chief Editor, Alan Lord, greatly improved the initial manuscript.

\section{Scientific editing by Clare Allen}

\section{References}

Bak, M. 1995. Mid Cretaceous Radiolaria from the Pieniny Klippen Belt, Carpathians, Poland. Cretaceous Research, 16, 1-23.

Bak, M. 1996. Cretaceous Radiolaria from Niedzica Succession of the Pieniny Klippen Belt in Polish Carpathians. Acta Paleontologica Polonica, 41, 91-101

Bak, M. \& Sawlowicz, Z. 2000. Pyritised radiolarians from the mid-Cretaceous deposits of the Pieniny Klippen Belt: A model of pyritization in an anoxic environment. Geologica Carpathica, 51, 91-99.

Barr, F.T. 1962. Upper Cretaceous planktonic foraminifera from the Isle of Wight, England. Palaeontology, 4, 552-580.

Bragina, L.G. 2004. Cenomanian-Turonian Radiolarians of Northern Turkey and the Crimean Mountains. Paleontological Journal, 38(suppl. 4), S323-S456.

Campbell, A.S. \& Clark, B.I. 1944. Radiolaria from Upper Cretaceous of Middle California. Geological Society of America Special Papers, 57, 1-61.

Cayeux, L. 1897. Contribution à l'étude micrographique des terrains sédimentaires. 1. Etude de quelques dépôts siliceux secondaires et tertiaires du Bassin de Paris et de la Belgique. 2. Craie du Bassin de Paris. Mémoires de la Société Géologique du Nord, 4, 1-591.

Curry, D. 1986. Foraminiferids from decayed chalk flints and some examples of their use in geological interpretation. In: Sieveking, G. de C. \& Hart, M.B. (eds) The Scientific Study of Flint and Chert. Cambridge University Press, Cambridge, 99-103.

Danelian, T. 2008. Diversity and biotic changes of Archaeodictyomitrid Radiolaria from the Aptian/Albian transition (OAE 1b) of southern Albania. Micropaleontology, 54, 3-13.

Danelian, T., Baudin, F., Gardin, S., Beltran, C. \& Masure, E. 2002. Early Aptian productivity increase as recorded in the Fourcade level of the Ionian zone of Greece. Comptes Rendus Geoscience, 334, 1087-1093.
De Wever, P., Dumitrica, P., Caulet, J.P., Nigrini, C. \& Caridroit, M. 2001. Radiolarians in the Sedimentary Record. Gordon \& Breach, London.

Dumitrica, P. 1970. Cryptocephalic and cryptothoracic Nassellaria in some Mesozoic deposits of Romania. Revue roumaine Géologie, Géophysique et Géographie, Bucarest, Série Géologie, 14, 45-124.

Earland, A. 1939. Chalk: Its riddles and some possible solutions. Transactions of the Hertfordshire Natural History Society, XXI, 6-37.

Ehrenberg, C.G. 1847. Über eine halibiolithische, von Herrn R. Schomburgk entdeckte, vorherrschend aus mikroskopischen Polycystinen gebildete, Gebirgsmasse von Barbados. Verhandlungen der Königlichen Preuss. Akademie der Wissenschaften Jahre, 1846, 382-385.

Ehrenberg, C.G. 1875. Fortsetzung der mikrogeologischen Studien als GesammtUebersichtder mikroskopischen Palaontologie gleichartig analysirter Gebirgsarten der Erde, mit specieller Rucksicht auf den PolycystinenMergel von Barbados. Abhandlungen der Königlichen Akademie der Wissenschaften zu Berlin, 1874, 1-225.

Ellison, R.A., Woods, M.A., Allen, D.J., Forster, A., Pharaoh, T.C. \& King, C. 2004. Geology of London. Special Memoir for 1:50 000 Geological Sheets 256 (North London), 257 (Romford), 270 (South London) and 271 (Dartford) (England and Wales). British Geological Survey, Keyworth.

Empson-Morin, K. 1981. Campanian Radiolaria from DSDP Site 313, MidPacific Mountains. Micropaleontology, 27, 249-292.

Foreman, H.P. 1966. Two Cretaceous radiolarian genera. Micropaleontology, 12, 355-359

Foreman, H.P. 1968. Upper Maastrichtian radiolarians of California. Special Papers in Paleontology, 3, 1-82.

Foreman, H.P. 1975. Radiolaria from the North Pacific, Deep Sea Drilling Project, Leg 32. In:Larson, R.L., Moberly, R. et al. (eds) Initial Reports of the Deep Sea Drilling Project, 32. US Government Printing Office, Washington, DC, 579-676.

Foreman, H.P. 1978. Mesozoic Radiolaria in the Atlantic Ocean off the northwest coast of Africa, Deep Sea Drilling Project, Leg 41. In: Lancelot, Y., Seibold, E. et al. (eds) Initial Reports of the Deep Sea Drilling Project, 41. US Government Printing Office, Washington, DC, 739-761.

Gorican, S. 1994. Jurassic and Cretaceous radiolarian biostratigraphy and sedimentary evolution of the Budva Zone (Dinarides, Montenegro). Mémoires de Géologie (Lausanne), 18, 1-177.

Haeckel, E. 1881. Entwurf eines Radiolarien-Systems auf Grund von Studien der Challenger- Radiolarien. Jenaische Zeitschrift für Naturwissenschaft, 15, 418-472.

Haeckel, E. 1887. Report on the Radiolaria collected by H.M.S. Challenger during the years 1873-1876. Report on the Scientific Results of the Voyage of the HMS Challenger, Zoology, 18, 1-1803.

Hashimoto, H. \& Ishida, K. 1997. Correlation of selected radiolarian assemblages of the Upper Cretaceous Izumi and Sotoizumi Groups and Shimanto Supergroup, in Shikoku. News of Osaka Micropaleontologists, Special Volume, 10, 245-257.

Hill, W. \& Jukes-Browne, A.J. 1895. On the occurrence of Radiolaria in Chalk. Quarterly Journal of the Geological Society of London, 51, 600-608, http:// doi.org/10.1144/GSL.JGS.1895.051.01-04.44

Hollis, C.J. 1997. Cretaceous-Paleocene radiolarians from eastern Marborough, New Zealand. Institute of Geological and Nuclear Sciences Limited, Lower Hutt, New Zealand.

Hollis, C.J. \& Kimura, K. 2001. A unified radiolarian zonation for the Late Cretaceous and Paleocene of Japan. Micropaleontology, 47, 235-255.

Holmes, W.M. 1900. On Radiolaria from the Upper Chalk at Coulsdon, Surrey Quarterly Journal of the Geological Society of London, 56, 694-704, http:// doi.org/10.1144/GSL.JGS.1900.056.01-04.38

Hopson, P.M. 2005. A stratigraphical framework for the Upper Cretaceous Chalk of England and Scotland, with statements on the Chalk of Northern Ireland and the UK Offshore Sector. British Geological Survey Research Report, RR/05/ 01, 1-102.

Jud, R. 1994. Biochronology and systematics of Early Cretaceous radiolaria of the Western Tethys 19. Mémoires de Géologie (Lausanne), 19, 1-147.

King, C. 2006. Paleogene and Neogene. In: Brenchley, P. \& Rawson, P.F. (eds) The Geology of England and Wales. 2nd edn. Geological Society, London, 395-427.

Kozlova, G.E. \& Gorbovetz, A.N. 1966. Radiolarii verchnemelovich $i$ verchneeocenovich otlozhenii Zapadno-Sibirskoy nizmennosti, 248. Trudy VNIGRI, Moscow [in Russian].

Kurilov, D.V. \& Vishnevskaya, V.S. 2011. Early Cretaceous Radiolarian Assemblages from the East Sakhalin Mountains. Stratigraphy and Geological Correlation, 19, 47-64.

Lipman, R.Kh. 1952. Data on the monographic study on radiolaria of the Upper Cretaceous deposits of the Russian platform. Trudy Vsesoyuznogo NauchnoIssledovatelskogo Geologogicheskogo Instituta (VSEGEI). Leninigrad, Paleontologiya i Stratigrafiya, 24-51 [in Russian].

Mortimore, R. 2011. A chalk revolution: What have we done to the Chalk of England? Proceedings of the Geologists' Association, 122, 232-297.

Musavu-Moussavou, B., Danelian, T., Baudin, F., Coccioni, R. \& Fröhlich, F. 2007. The Radiolarian biotic response during OAE2. A high-resolution study across the Bonarelli level at Bottacione (Gubbio, Italy). Revue de Micropaléontologie, 50, 253-287. 
O’Dogherty, L. 1994. Biochronology and Paleontology of Mid-Cretaceous Radiolarains from Northern Apennines (Italy) and Betic Cordillera (Spain). Mémoires de Géologie (Lausanne), 21.

O’Dogherty, L., Carter, E.S., Dumitrica, P., Goričan, S., De Wever, P., Bandini, A.N. \& Baumgartner, P.O. 2009. Catalogue of Mesozoic radiolarian genera. Part 2: Jurassic-Cretaceous. Geodiversitas, 31, 271-356.

Okamoto, S., Kojima, S., Suparka, S. \& Supriyanto, J. 1994. Campanian (Upper Cretaceous) radiolarians from a shale clast in the Paleogene of central Java, Indonesia. Journal of Southeast Asian Earth Sciences, 9, 45-50.

Packer, S.R. \& Hart, M.B. 2005. Coniacian-Santonian Radiolaria from the Upper Cretaceous of Bornholm, Denmark: A preliminary investigation. Bulletin of the Geological Society of Denmark, 52, 141-157.

Pessagno, E.A. 1963. Upper Cretaceous radiolaria from Puerto Rico. Micropaleontology, 9, 197-214.

Pessagno, E.A. 1971. Jurassic and Cretaceous Hagiastridae from the Blake-Bahama Basin (Site 5A, JOIDES Leg 1) and the Great Valley Sequence, California Coast Ranges. Bulletins of American Paleontology, 60/264, 5-83.

Pessagno, E.A. 1973. Upper Cretaceous Spumellariina from the Great Vallley Sequence, California Coast Ranges. Bulletins of American Paleontology, 63/ 276, 49-102.

Pessagno, E.A. 1976. Radiolarian zonation and stratigraphy of the Upper Cretaceous portion of the Great Valley sequence. Micropaleontology, Special Publications, 2, 1-96.

Pessagno, E.A. 1977. Lower Cretaceous radiolarian biostratigraphy of the Great Valley Sequence and Franciscan Complex, California Coast Ranges. Cushman Foundation for Foraminiferal Research, Special Publication, 15, $5-87$

Popova-Goll, I., Vishnevskaya, V. \& Baumgartner, P.O. 2005. Upper Cretaceous (Santonian-Campanian) radiolarians from Voronesh Anticline, southwestern Russia. Micropaleontology, 51, 1-37.
Riedel, W.R. 1967. Subclass Radiolaria. In: Harland, W.B., Holland, C.H. et al (eds) The Fossil record. A symposium with documentation. Geological Society, London, 291-298.

Riedel, W.R. 1971. Systematic classicification of Polycystine Radiolaria. In: Funnell, B.M. \& Riedel, W.R. (eds) The Micropaleontology of the Oceans. Cambridge University Press, Cambridge, 649-661.

Royse, K.R. 2010. Combining numerical and cognitive 3D modelling approaches in order to determine the structure of the Chalk in the London Basin. Computers \& Geosciences, 36, 500-511.

Rüst, D. 1888. Beiträge zur Kenntniss der fossilen Radiolarien aus Gesteinen der Kreide. Palaeontographica, 34, 181-213.

Smreckova, M. 2011. Lower Turonian radiolarians from the Cervena skala section (Pieniny Klippen Belt, Western Carpathians). Mineralla Slovaca, 43, 31-38.

Squinabol, S. 1903. Le radiolaire dei nodule selciosi nella Scaglia degli Euganei. Contribution I. Rivista Italiana di Paleontologia, 9, 105-151.

Taketani, Y. 1982. Cretaceous Radiolarian Biostratigraphy of the Urakawa and Obira areas. Hokkaido Tohoku University Sendai, Scientific Reports, Seria 2, Geology, 52, 1-76.

Vishnevskaya, V.S. 2001. Radiolarian Biostratigraphy of the Jurassic and Cretaceous of Russia. GEOS, Moscow.

Vishnevskaya, V.S. \& De Wever, P. 1998. Upper Cretaceous Radiolaria from the Russian Platfom (Moscow Basin). Revue de Micropaléontologie, 41, 235-265.

White, M.P. 1928. Some index foraminifera of the Tampico Embayment area of Mexico. Journal of Paleontology, 2, 280-317.

Wilkinson, I.P. 2011. Foraminiferal biozones and their relationship to the lithostratigraphy of the Chalk Group of Southern England. Proceedings of the Geologists' Association, 122, 842-849.

Zittel, K.A. 1876. Über einige fossile Radiolarien aus der norddeutschen Kreiden Zeitschrift der Deutschen Geologischen Gesellschaft, 28, 75-87. 